BASINDO : Jurnal Kajian Bahasa, Sastra Indonesia, dan Pembelajarannya

Volume 2 Nomor 1, 2018

Journal homepage : http://journal2.um.ac.id/index.php/basindo

\title{
RECALL MEMORY PADA DONGENG KARANGAN SISWA KELAS VII SMP
}

\author{
Nani Nurcahyani* \\ Universitas Negeri Surabaya, Indonesia
}

\begin{tabular}{|c|c|}
\hline A R T I L E I N F O & A B S T R AC T \\
\hline $\begin{array}{l}\text { Keyword: } \\
\text { recallmemory, } \\
\text { dongeng karangan, } \\
\text { SMP }\end{array}$ & $\begin{array}{l}\text { Memori merupakan salah satu bagian integral dari eksistensi manusia. Aktivitas } \\
\text { belajartidak lepas dari proses mengingat. Kemampuan siswa dalam menulis bergantung } \\
\text { pada input, storage, dan output. Proses mengingat input yang disimpan dalam otak dengan } \\
\text { recall memory. Penelitian ini bertujuan mendeskripsikan proposisi bentuk dan makna } \\
\text { asosiatif pada dongeng karangan siswa SMP. Pendekatan penelitian ini adalah kualitatif } \\
\text { deskriptif. Metode pengumpulan dan penganalisisan data adalah intertekstualitas. Hasil } \\
\text { penelitian menunjukkan bahwa (1) proposisi bentuk didominasi bentuk majemuk- } \\
\text { majemuk - delisi karena siswa kelas VII mencapai daya ingat paling besar dan mampu } \\
\text { meniru proposisi bentuk majemuk ke majemuk;dan (2) makna asosiatif didominasi } \\
\text { makna reflektif-reflektif karena cara pandang siswa menemukan makna potensial bahasa } \\
\text { dalam dongeng karangannya dan mengomparasi antara hipogram dan teks transformasi. } \\
\text { Oleh karena itu, untuk meningkatkan kemampuan memori dan menulis perlu latihan dan } \\
\text { motivasi. }\end{array}$ \\
\hline
\end{tabular}

\section{PENDAHULUAN}

Salah satu bagian integral dari eksistensi manusia adalah memori. Manusia mengetahui apa yang ada di dunia ini bukan hanya dari pengetahuan sejak lahir saja, melainkan sebagian besar dari pengalaman yang disimpan dalam memori. Manusia mengetahui nama pantai, kota, dan lainnya karena hal tersebut pernah menjadi bagian dari pengalaman hidup yang kemudian disimpan dalam memori. Tidak dapat dibayangkan seperti apa manusia bila tidak dapat mengingat masa lalu, menyimpan masukan yang baru saja didengar, dan mengingat apa yang akan dilakukan besok.

Clark dan Clark (1977:134-136); Engel(2000:5) menyatakan bahwa memori dibentuk dan dipakai melalui tiga tahap yaitu input, penyimpanan, dan output. Pada tahap input, orang menerima masukan, baik lisan maupun tulisan, pasif maupun aktif. Kemudian memberikan interpretasi tentang masukan itu untuk dipahami. Orang lebih memperhatikan makna daripada kata-katanya. Oleh karena itu, orang bukan menyimpan kata- kata yang didengar atau dibaca tetapi isi atau makna dari keseluruhan kata- kata tersebut. Ketika orang ingin mengutarakan kembali mengenai hal yang baru saja didengar atau dibaca, orang tidak akan memakai kata-kata yang sama persis dengan input yang didapatkannya.

Penelitian tentang memori menarik untuk diteliti karena kemampuan tiap orang tidak sama dalam mengingat sesuatu. Kemampuan mengingat menunjukkan bahwa manusia mampu menerima, merasakan, mengolah, menyimpan, merespon, dan menimbulkan kembali pengalaman-pengalaman yang dialaminya (Walgito, 2004). Kegiatan manusia untuk mengambil atau mengingat kembali pengetahuan dan informasi dipelajarinya dari masa lalu. Pada umumnya kemampuan recall memory sangat Berperan pada saatdiadakan tes evaluasi belajar. Tes ini dapat dilaksanakan individu pada ujian akhirsemester.Testes tersebut membutuhkan kemampuan recall memory yang cukup tinggi. Tujuan dari dilaksanakannya tes evaluasi belajar adalah mengetahui kemampuan siswa dalam mengingat kembali materi pelajaran yang telah dipelajarinya.

\footnotetext{
* Corresponding author.

E-mail addresses: nani.sumawe@gmail.com (Nani Nurcahyani)
}

ISSN : 2579-3799 (Online) - BASINDO : Jurnal Kajian Bahasa, Sastra Indonesia, dan Pembelajarannya is licensed under Creative Commons Attribution-ShareAlike 4.0 International License (http://creativecommons.org/licenses/BY/4.0/).

65 | BASINDO : Jurnal Kajian Bahasa, Sastra Indonesia, dan Pembelajarannya 


\section{a. Recall Memory}

Recall memory(RM) merupakan proses membangkitkan atau mengembalikan lagi ingatan, secara verbal atau perbandingan nyata, suatu pengalaman di masa lalu menurut Drever (1986). Membangkitkan kembali pengalaman-pengalaman yang pernah dialami, sama halnya dengan menimbulkan kembali sesuatu yang pernah terjadi dan tersimpan dalam ingatan. Memori tersebut dipakai untuk membangun konsep. Konsep tersebut berdasarkan masukan.

RM merupakan suatu tipe pengembalian ingatan dengan isyarat minimal yang membuat manusia dapat mengingat kembali pengalaman atau informasi yang pernah dipelajari sebelumnya (Kartono, 2003). Sementara itu, Chafe (1973), mengemukakan bahwa dalam RM, dihadirkan suatu kesan dari masa lampau dalam bentuk suatu tanggapan atau gagasan, tetapi hal yang diingat itu tidak hadir pada saat mengingat kembali. Berdasarkan pejelasan di atas maka dapat disimpulkan bahwa pada waktu mengingat kembali, manusia memproduksi apa yang pernah dijumpai tanpa berkontak kembali dengan hal yang pernah dijumpai itu.

Sternberg (2006), menyatakan bahwa dalam RM manusia harus mereproduksi sebuah fakta, kata, atau hal lain dalam memorinya, sehingga RM umumnya menghasilkan tingkat ingatan yang lebih dalam. Menurut Walgito (2004), RM merupakan bentuk mengingat yang lebih sukar, seperti mengingat rangkaian kejadian yang pernah terjadi pada masa lalu. RM berarti mengingat kembali atau mereproduksi kembali fakta-fakta atau informasi dari ingatan. Kemampuan RM pada umumnya diperlukan dalam tes esai, karena dalam bentuk tes ini manusia diharuskan untuk menimbulkan kembali apa yang diingat tanpa dibantu adanya objek sebagai stimulus untuk dapat diingat kembali. Kemampuan RM juga berarti kemampuan untuk mereproduksi atau menimbulkan kembali informasi dengan meminimalisasi stimulus eksternal.

Definisi-definisi mengenai RM mempunyai persamaan yaitu kemampuan untuk mengingat memori yang disimpan pada masa lalu. Memori yang muncul bergantung berapa lama dan kuat memori tersebut disimpan. Selain itu, stimulus juga memengaruhi memori manusia. Jadi, dapat disimpulkan bahwa recall memory adalah kemampuan manusia untuk mengingat kembali pengalaman atau informasi yang disimpan tanpa adanya objek sebagai stimulus.

Aktivitas belajar tidak lepas dari proses mengingat (Djamarah, 2003), terutama masa kanak-kanak, karena pada masa tersebut terjadi perkembangan memori yang sangat pesat, begitu pula dengan kemampuan mengingatnya. Penyimpanan hasil belajar atau informasi yang diperoleh agar dapat digunakan kembali suatu saat maka informasi tersebut harus disimpan dalam memori.

Memori berperan penting dalam pembelajaran bahasa. Pembelajaran bahasa bertujuan meningkatkan kemampuan berkomunikasi siswa dalam bahasa Indonesia dengan baik dan benar, baik secara lisan maupun tulis, serta menumbuhkan apresiasi terhadap hasil karya kesastraan manusia Indonesia (BSNP,2006:2). Berdasarkan tujuan tersebut, pembelajaran Bahasa Indonesia tidak sekadar untuk meningkatkan keterampilan berbahasa, tetapi meningkatkan kompetensi berbahasa. Berbahasa bukan merupakan keterampilan mekanis yang diajarkan dengan pelatihan-pelatihan. Berbahasa berhubungan erat dengan prosesberpikir.

Kemampuan siswa SMP dalam menulis kurang. Buktinya, mereka membutuhkan waktu yang lama dalam menuangkan gagasannya. Buku tulis yang ada di hadapannya tetap kosong, tidak ada kalimat yang dituangkannya. Mereka bingung ketika menuangkan ide. Siswa tidak terbiasa menulis karena menulis bukan sekadar kebiasaan. Kemampuan menulis siswa juga dipengaruhi oleh memori yang disimpan. Siswa mengalami kesulitan dalam mengorganisasi Konsep dan mengeluarkan kembali kata-kata yang tersimpan dalam memorinya. Misal, Kompetensi Dasar "Menulis kembali dengan bahasa sendiri dongeng yang pernah dibaca atau didengar".

\section{b. Dongeng}

Siswa membutuhkan objek bantu untuk membantu proses berpikirnya dalam mengoptimalkan kemampuan RM. Objek bantu tersebut dapat berupa media audiovisual, bukuteks, dongeng, gambar, musik, dan lain- lain. Dalam penelitian ini, digunakan dongeng sebagai objek bantu. Kelebihan dongeng dibandingkan alat bantu yang lain adalah antusias siswa terhadap dongeng tinggi. Dongeng merupakan cerita yang diyakini kebenarannya oleh masyarakat secara turun-temurun. Selain itu, dongeng merupakan sastra lisan yang mempunyai fungsi sebagai alat untuk mendidik (pedagogical device) dan menghibur (Danandjaya, 1977). Dongeng diharapkan dapat membangkitkan ketertarikan siswa dalam menulis sehingga siswa lebih memerhatikan dan menyimaknya dengan seksama. Penjelasan materi pelajaran yang masih konvensional dan kurang menarik bagi siswa menyebabkan mudah bosan dan sulit untuk memahami materi yang disampaikan. Fenomena yang terjadi sekarang adalah siswa mudah 
mengingat cerita dongeng yang berasal dari komik atau televisi dari pada materi pelajaran yang disampaikan disekolah. Olehkarena itu,penyampaian materi pelajaran dengan menggunakan metode cerita, dongeng, atau fiksi lebih memotivasi siswa untuk memahami materi yang diperolehnya.

Karakteristik siswa SMP sudah mampu berpikir secara abstrak dan mampu berimajinasi dengan pikirannya. Hal tersebut sesuai dengan teori Piaget (dalam Yusuf, 2001:184) yang menyatakan bahwa Periode anak usia 12 tahun keatas merupakan period of formal operation, maksudnya kemampuan berpikir siswa pada usia ini sudah mampu memahami sesuatuyang bermakna (meaningfully) tanpa memerlukan objek konkret atau visual. Dongeng merupakan objek yang tidak konkret dan mempunyai daya tarik bagi siswa SMP.

Berdasarkan fenomena tersebut, RM menarik untuk diteliti dari aspek proposisi bentuk dan makna asosiatif dikaji dengan psikolinguistik. Penelitian psikolinguistik tidak hanya meneliti bentuk saja, melainkan isiya. Berdasarkan bentuknya, penelitian ini difokuskan pada proposisi bentuk dan berdasarkan isinya, difokuskan pada makna asosiatif.

\section{c. Proposisi Bentuk}

Proposisi bentuk yang terdapat dalam karangan siswa adalah proposisi tunggal dan majemuk menurut Euler (dalam Mundiri, 2009). proposisi tunggal dan majemuk dilihat dari jumlah Pernyataan dan subjek dan predikat yang ada dalam proposisi tersebut. Proposisi tunggal merupakan proposisi yang terdiri atas satu pernyataan dan satu subjek dan perdikat, sedangkan proposisi majemuk merupakan proposisi yang terdiri atas pernyataan dan subjek serta predikat yang jumlahnya lebih dari satu. Selain itu, proposisi tunggal dan majemuk sudah diajarkan pada siswa kelas VII.

\section{d. Makna Asosiatif}

Makna dalam dongeng karangan siswa dilihat berdasarkan jenis makna. Menurut Leech (2003), ada tujuh jenis makna yaitu makna konseptual, makna konotatif, stilistik, makna afektif, reflektif, makna kolokatif, dan maknatematik. Leech mengelompokkan kelima makna yang berasosiasi dengan kata lain di luar bahasa tersebut menjadi satu. Makna yang berasosiasi tersebut disebut makna asosiatif. Makna asosiatif tersebut terbagi atas lima jenis yaitu makna konotatif, makna stilistik, makna afektif, makna reflektif, dan makna kolokatif.

Data yang diambil dalam penelitian ini dikhususkan pada makna asosiatif karena recall memory bukan menitik beratkan pada kata-kata tetapi pada isinya. Makna kali pertama masuk kemudian disimpan dan dikeluarkan lagi dapat persis seperti makna yang diperoleh dan dapat juga berbeda. Makna yang terdapat pada teks asli dapat berubah atau tidak, ketika ditulis ulang oleh siswa. Makna kata pada karangan siswa dapat berasosiasi dengan hal lain diluar bahasa.

\section{e. Karangan}

Keterampilan berbahasa ada empat yaitu menulis, membaca, menyimak, dan berbicara. Salah satu wujud kegiatan praktik menulis adalah mengarang. Mengarang erat hubungannya dengan bahasa. Oleh karena itu kecakapan berbahasa merupakan modal utama dalam mengarang (Shinta, Chamalah, \& Arsanti, 2018). Modal pengetahuan bahasa diberikan di sekolah dan dilatih penggunaanya dalam kegiatan menulis. Tuntutan mengarang tidak hanya terletak pada pengetahuan teori saja melainkan praktiktulis- menulis.

Menulis merupakan salah satu aspek keterampilan berbahasa. Menulis melibatkan berbagai unsur keterampilan harus dikonsentrasikan agar menghasilkan tulisan yang benar-benar baik. Menulis dapat diartikan sebagaiaktivitas komunikasi menggunakan bahasa tulisan yang sebagai medianya. komunikasi Sebagai bahasa, bentuk tulisan merupakan kegiatan penyampaian pesan. Gie dalam buku'Pengantar Dunia Karang-Mengarang' menyebutkan bahwa balai bimbingan mengarang tidak membedakan arti kata 'mengarang' dan 'menulis'. Sinonim tersebut akan dipakai bergantian untuk mencegah kesenadaan atau kelaziman ucapan atau rasa kebahasaan. Gie (1992:7) berpendapat bahwa karang-mengarang adalah segenap rangkaian kegiatan manusia mengungkapkan buah pikiran melalui bahasa tulis untuk dibaca dan dimengerti orang lain. Berbeda dengan Gie,Tarigan (1995:3) menyatakan bahwa menulis merupakan suatu keterampilan berbahasa yang digunakan untuk berkomunikasi secara tidak langsung, tidak bertatap muka dengan orang lain. Menulis merupakan aktivitas berkomunikasi dengan menggunakan bahasa tulis sebagai medianya. 
Mengarang pada hakikatnya bukan sekadar menuliskan lambang- lambang grafik sehingga membentuk kata, kemudian kata-kata itu disusun menjadi kalimat menurut peraturan tertentu tetapi mengarang adalah menuangkan pikiran kedalam bahasa tulisan melalui kalimat-kalimat yang dirangkai secara utuh, lengkap, dan jelas sehingga pikiran tersebut dapat berhasil dikomunikasikan kepada pembaca (Byrne,1971).

Dapat disimpulkan bahwa karangan adalah tulisan yang berisi ide atau gagasan melalui kalimat- kalimat yang dirangkai secara utuh, lengkap, dan jelas dan mempunyai tujuan tertentu untuk dikomunikasikan kepada pembaca. Jika pembaca mampu menangkap makna yang disampaikan dalam karangan, tujuan dari penulisan karangan tersebut telah tercapai. Karangan merupakan hasil proses mental berupa bahasa tulis.

\section{f. Intertekstualitas}

Karangan merupakan cakupan dari wacana. Wacana disebut juga teks. Teks mudah dipahami jika disertakan konteks. Teks terdiri atas rangkaian kalimat yang panjang. Teks merupakan satu permutasian teks-teks lain. Intertekstual memandang teks berada di dalam ruang satu teks yang ditentukan, teks merupakan bermacam-macam tindak ujaran, teks diambil dari teks-teks lain, serta teks bersifat tumpang- tindih dan saling menetralkan satu sama lain (Kristeva,1980:36-37). Kajian intertekstual berangkat dari asumsi bahwa kapanpun karyatulis, ia tidak mungkin lahir dari situasi kekosongan budaya. Penulisan suatu karya sastra tak mungkin dilepaskan dari unsur kesejarahannya, dan pemahaman terhadapnya pun haruslah mempertimbangkan unsur kesejarahanitu.

Makna keseluruhan karya secara penuh baru dapat digali dan diungkap secara tuntas dalam kaitannya dengan unsur kesejarahan tersebut. Karena itu, teks sastra dibaca dengan latar belakang teks- tekslain, tidak ada tekspun yang sungguh-sungguh mandiri, dalam arti bahwa penciptaan dan pembacaannya tidakdapat dilakukan tanpa adanya teks-teks lain. Teks yang menjadi latar penciptaan karya baru disebut hipogram, dan teksbaru yang menyerapdan mentransformasikan hipogram disebut teks transformasi (Riffaterre, 1978).

Pemikiran Kristeva mengenai intertekstualitas dapat dijabarkan sebagai berikut, kehadiran suatuteks di dalam teks yang lain, selalu adanya petunjuk yang menunjukkan hubungan antara suatu teks dengan teks-teks pendahulu. Adanya fakta bahwa penulis suatu teks pernah membaca teks-teks pemengaruh sehingga nampak jejak. Pembaca teks tidak dapat membaca teks secara pisah dengan teks-teks lainnya. Ketika membaca teks, manusia membacanya berdampingan dengan teks-teks lain.

Tujuan kajian intertekstualitas adalah memberikan makna secara penuh terhadap karya. Penulisanatau pemunculan sebuah karya ada kaitannya dengan unsur kesejarahannya, sehingga pemberian maknaitu akan lebih lengkap jika dikaitkan dengan unsur kesejarahan itu(Teeuw,1983:62$65)$.

Penenlitian ini bertujuan mendeskripsikan recall memory pada dongeng karangan siswa kelas VII SMP. Tujuan khusus penelitian ini adalah mendeskripsikan proposisi bentuk dan makna asosiatif pada dongeng karangan siswa kelas VII SMP.

\section{METODE}

Pendekatan yang digunakan dalam penelitian ini adalah kualitatif. Data dianalisis dengan mendeskripsikan RM dongeng karangan siswa, meliputi proposisi bentuk dan makna asosiatif pada RM dongeng karangan siswa. Jenis penelitian ini adalah deskriptif. Tujuan penelitian ini mendeskripsikan secara rinci dan dalam tentang proposisi bentuk dan makna asosiatif pada RM dongeng karangan siswa.

Data penelitian ini adalah kata, frasa, klausa, dan kalimat yang terdapat pada dongeng karangan siswa kelas VII SMP. Sumber data penelitian ini adalah dongeng karangan yang dihasilkan subjek penelitian. Subjek dalam penelitian ini adalah siswa kelas VII SMP.

Pengumpulan data dalam penelitian ini dilakukan melalui teknik penugasan. Instrumen pengumpulan data yang digunakan dalam penelitian ini adalah lembar soal dan pedoman soal. Metode analisis data yang digunakan untuk menjawab fokus1dan 2 dalam penelitian ini adalah metode intertekstualitas. Instrumen penganalisisan data dalam penelitian ini adalah kartu data. Analisis data penelitian ini dilakukan melalui empat tahap yaitu menentukan (1) alasan sastra dan sosialbudaya, (2) bentuk transformasi, (3)dampak teks transformasi terhadap genre baru, (4) hipogram.

Tempat penelitian adalah SMP Negeri 1 Tumpang, beralamat di Jalan Raya Malangsuko Nomor 22 Tumpang Kabupaten Malang. SMP Negeri 1 Tumpang Kabupaten Malang dipilih karena sekolah ini 
merupakan salah satu sekolah unggulan diKabupaten Malang. Sebanyak 67\% guru bidang studi Bahasa Indonesia di SMP Negeri1Tumpang merupakanlulusan S2.

HASIL

Berdasarkan analisis data didapatkan hasil kajian sebagai berikut.

1. Proposisibentukterdiri atas majemuk-majemuk- delisi, majemuk-majemuk-substitusi, majemuk

- tunggal - delisi, tunggal-majemuk- substitusi, tunggal- tunggal-substitusi, majemuk

majemuk, majemuk - tunggal - substitusi, tunggal - tunggal, dan tunggal - tunggal- delisi.

Dari hasil analisis proposisi bentuk pada RM dongeng karangan siswa menunjukkan dominasi proposisi bentuk majemuk- majemuk-delisi pada RM dongeng karangan siswa. Penggolongan proposisi dikaji dari bentuk apakah berpengaruh banyak atau minim. Dalam hal ini ukuran tidak ada yang mutlak, melainkan diambil dari kecenderungan atau kedominanan.

Proposisi merupakan pernyataan tentang hubungan antara dua atau beberapa hal yang dapat dinilai benar atau salah. Proposisi terdiri atas pengakuan atau (1) Setelahtiga hari kejadian itu terjadi, Dewa Brahma menemui Ken Endok di Tegal Lelateng.

DAT.Pb.Tg.007 pengingkaran.

Menurut Mundiri (2009), proposisi bentuk terdiri atas proposisi tunggal dan majemuk. Proposisi tunggal terdiri atas satu pernyataan yang berisi satu subjek dan satu predikat sebagai unsur inti. Proposisi majemuk terdiri atas dua atau lebih pernyataan yang berisi dua atau lebih subjek dan predikat. Contoh proposisi bentuk yang terdapat dalam penelitian ini adalah sebagai berikut.

Proposisi Majemuk - Majemuk- Delisi

Sebagaimana telah dinyatakan pada bab sebelumnya, proposisi majemuk merupakan proposisi yang terdiri atas dua atau lebih pernyataan. Proposisi majemuk diindikasikan dengan adanya dua atau lebih subjek dan predikat. Berikut ini data yang menunjukkan proposisi majemuk-majemuk- delisi.

Selang tiga hari setelah peristiwa itu ketika Ken Endok berjalan pulang dari mengirim makanan untuk suaminya, si Dewa Brahma kembali menemuinya ditengah Tegal Lelateng.

Data (1) merupakan proposisi majemuk yang terdiri atas dua pernyataan yaitu Setelah tiga hari kejadian itu terjadi dan Dewa Brahma menemuiKen Endok diTegal Lelateng. Pada data (1) terdapat dua subjek dan dua predikat. Kejadian itu danDewa Brahma adalah subjek,terjadi danmenemui merupakan predikatyang menjadi unsur inti. Ken Endok adalahobjek, diTegal Lelateng merupakan keterangan yang menjadi unsurtambahan.Data (1) merupakan tekstransformasi dari hipogram Selang tigahari setelah peristiwa itu ketika Ken Endok berjalan pulangdari mengirim makanan untuksuaminya, si DewaBrahma kembali menemuinyadi tengahTegal Lelateng.Hipogram tersebut merupakan proposisi majemuk yang terdiri atas tiga pernyataan yaitu (1) selang tiga hari setelah peristiwaitu,(2)Ken Endok berjalan pulang dari mengirim makananuntuk suaminya,dan(3)si Dewa Brahma kembali menemuinya ditengahTegal Lelateng. Hipogramtersebut terdiriatas tiga subjek dan tigapredikat. (1) Peristiwa itu, (2) Ken Endok, dan(3)siDewa Brahma merupakan subjek, predikat yangmenjadi unsur inti. Makananmerupakan objek,pulang merupakan pelengkap, dandi tengah Tegal Lelatengmerupakan keterangansebagai unsur tambahan.

Kata Dewa Brahma pada data(1) menunjukkan kesejajaran gagasan dengan si Dewa Brahma pada hipogram.Kata Dewa Brahma pada data (1) bermaknaTuhan padaagama Hinduyang berperan menciptakan alam semesta. KataDewa Brahma mengacu pada sesuatu yang dipuja- puja.Data(1) menunjukkan bahwa Dewa Brahma menemuiken Endokkembali diTegalLelateng setelahtiga hari yang lalu. Berbeda berjalan dan kembali menemuinya merupakan halnya dengan si Dewa Brahma pada hipogram tersebut bermakna julukan untuk DewaTrimurti. Makna tersebutdiperkuat dengan adanya kata sandang ' $\mathrm{si}$ '.Katasi DewaBrahmapada hipogram tersebutmengacu padadewayang sangat dihormatidikalangan umat Hindu.Hipogram menunjukkanbahwa Dewa Brahma menemuiKen Endok diTegalLelateng ketikaKen Endok mengirim makanan untuksuaminya.

Hipogram kedata(1) merupakanproposisi bentuk majemuk ke majemuk. Data (1) merupakanteks transformasidari hipogram dengan melesapkansalahsatu unsur. Bentuk yang dilesapkan adalah si.Terdapatperbedaan ketika pembaca menginterpretasiDewa Brahma pada data (1) dansi DewaBrahmapada hipogram. Kata Dewa Brahma pada data (1) mengekspresikan kecintaanumat pada 
dewa pencipta alamsemesta,sedangkan si Dewa Brahma pada hipogram mengekspresikan keakraban pemujapadasangdewa.

Data(1)dan hipogram diekspresikan secara padat olehpengarang.Padadata (1) menekankan penggunaan Dewa Brahma,sedangkan hipogram menekankan penggunaan siDewaBrahma. Hipogram berdampak pada transformasi data(1). Hipogram menyebabkan terjadinyagenrebaru, dari bentuk siDewa Brahma menjadi DewaBrahma. Penggunaansi DewaBrahma dan DewaBrahmadapat memengaruhi pembaca.Hipogram merupakan sumbangan yang menimbulkanberbagai efek pemaknaanpada pembaca.Hipogram diadaptasi pengarangmenjadi data(1).Datayangdiadaptasi adalah Selang tigahari setelah peristiwa itu ketika Ken Endokberjalan pulang dari mengirim makananuntuk suaminya,si DewaBrahma kembali menemuinya di tengahTegal Lelateng.Unsur lain yang dilesapkan adalah Ken Endok berjalan pulang dari mengirim makanan Malin

stilistik, makna konotatif - reflektif, makna konotatif - stilistik,makna konotatif - reflektif.

Contoh analisis makna reflektif -reflektif. Makna reflektif adalah makna yang muncul dalam halmaknakonseptual ganda, jika suatu pengertian sepenggal kata membentuk sebagian respon pendengar atau pembacaterhadap pengertianlain.Berikut data yangmenunjukkan makna reflektif -reflektif. (2) Malin adalah salah satu orang yang terkena wabah penyakit tersebut.

SLM.Ma.Rr.026 untuk suaminya.

2. Makna asosiatif yang ditemukan dalam penelitian ini beragam,sebagaimana diungkapdalamteori bahwa makna asosiatif terdiri atas lima jenis yaitu makna konotatif, makna stilistik, makna afektif, makna reflektif,danmakna kolokatif (Leech,2003). Berdasarkan analisisdata,diurutkan dari jumlah terbanyak hingga yang paling sedikit, antara lain: makna reflektif - reflektif, makna stilistik - stilistik,maknakonotatif - konotatif,maknakolokatif kolokatif, makna afektif- afektif, makna reflektif -Malin Kundang termasuk salah satu orang yang terserang penyakit itu.

Data(2)merupakan proposisi tunggal yang terdiri atas satu pernyataan yaitu Malin adalah salah satu orang yang terkena wabah penyakittersebut. Padadata(2) terdapat satusubjek dan satu predikat. Malinadalahsubjek,adalah salah satu orang yang terkenawabah penyakit tersebut merupakan predikat yang menjadi unsurinti.Data (2) merupakan teks transformasi dari hipogram Malin Kundangtermasuksalahsatu orang yang terserang penyakit itu.

Hipogram merupakan proposisi tunggal yang terdiri atas satu pernyataan yaitu Malin Kundang adalah salah satu orang yang terserang penyakit tersebut. Hipogramterdiri atassatusubjekdan satu predikat. Malin Kundangadalah subjek dan adalah salah satu orang yang terserang penyakit tersebut adalah predikat yang menjadi unsur inti.

Padadata(2)terdapat kata terkena.Kata terkenamemunyai makna ganda. Makna kataterkena yangpertamaadalah bersentuhan. Makna kata terkena yang kedua adalah tertimpa.Maknakataterkena memunyai maknalaindengancara melihat dayasugestif yang dominan ataumelalui kekuatanasosiasinya. Kekuatanasosiasidari kataterkena dapatdilihatdari katalainyang menyertai. Kata lainyang menyertai kataterkenaadalah wabah penyakit. Jadi, maknakataterkenayangbenar adalahtertimpapenyakit.

Terkena pada data (2) menunjukkan kesejajaran gagasan dengan terserang pada hipogram.Kataterkenapadadata(2) bermakna tertimpa.Kataterkenamengacupada wabah penyakit. Berbeda halnya dengan terserang pada hipogram. Pada hipogramterdapat kata terserang.Kataterserang memunyai maknaganda.Makna kata terserang yang pertama adalah terkena serangan.Maknakataterserangyang keduaadalah terjangkit.Maknakata terserang memunyaimakna lain dengan cara melihat daya sugestif yangdominanataumelalui kekuatan asosiasinya. Kekuatan asosiasi dari kata terserang dapatdilihatdarikata lain yang menyertai. Kata lainyang menyertai kataterserang adalah penyakit itu. Jadi, makna kata terserang yang benar adalah terjangkit penyakit.

Hipogram kedata(2)merupakan proposisi tunggal ke tunggal.Data (2) merupakanteks transformasidari hipogram dengan menyubstitusi salah satu unsur.Bentukyang disubstitusi adalah terserang.Terdapatperbedaan ketikapembaca menginterpretasi terkena pada data (2)dan terserang padahipogram.Terkena pada data (2) mengekspresikan kesedihan, sedangkan terserang padahipogram mengekspresikan ketakutan.

Data(2)dan hipogram diekspresikan secarapadatoleh pengarang.Pada data (2) menekankanpenggunaan terkena, sedangkanhipogram menekankan penggunaan terserang.Hipogram 
berdampak pada transformasi data (2).Hipogram menyebabkanterjadinyagenrebaru,dari bentuk terserang menjadi terkena. Penggunaan terkena dan terserang dapat memengaruhi pembaca. Hipogram merupakan sumbangan yangmenimbulkanberbagai efek pemaknaan padapembaca.Hipogram diadaptasi pengarang menjadi data (2).Data yang diadaptasi adalah MalinKundangtermasuksalah satu orangyangterserangpenyakititu.

\section{PEMBAHASAN}

Hasil penelitianmenunjukkan bahwa (1) recall memory teraktualisasi dalam imitasi bentuk. Dari hasilanalisis proposisi bentuk pada RM dongeng karangan siswa menunjukkan dominasi proposisi bentukmajemuk-majemuk- delisi padaRMdongeng karangan siswa. Penggolonganproposisi dikaji dari bentuk apakah berpengaruhbanyak atau minim. Dalam halini ukuran tidakadayang mutlak,melainkan diambildarikecenderungan atau kedominanan.kemampuanRMsiswa kelas VII dalam mengarang kuat. Siswa mampu meniru proposisi bentukmajemukkemajemuk dalam karangannya.Proposisi bentukmajemuk didasarkanadanyaduaatau lebihpernyataandalam satukalimat yang terdiri atas dua atau lebih subjekdanpredikat.Proposisi bentuk majemuk dalam dongeng karangan siswakelasVIIadayang sama bentuknya danada yang beda dari teksdongeng asli.Perbedaan bentuk tersebutberupapendelisian dan penyubstitusian data. Pendelisian data dilakukan dengan melesapkan unsur tertentu dariteksdongengasli, sedangkan penyubstitusian data dilakukandenganmengganti unsur tertentu dariteks dongeng aslitanpa mengubahmaknayang ingin disampaikan. Variasi bentuk ditemukandalam dongengkarangan siswa dengancara substitusi. Misal bentuk tak langsung menjadi langsung atau sebaliknya, bentuk afektif- afektif. Wujud temuanyang berbedaadalahmaknakonotatif - reflektif. Wujud temuan yangsama dan berbeda bergantung cara pandang siswa dalammengarang, karenadongeng karangan siswa merupakankomparasidari hipogram dan tekstransformasi.

(2) recallmemory terejawantah dalam komparasi maknaasosiatif. Variasi makna asosiatif ditemukan pada dongeng karangan siswa.Maknapada hipogram ada yang samadan berbeda. Wujud temuan yang samaadalah maknareflektif- reflektif, stilistik - stilistik, konotatif

- konotatif, kolokatif - kolokatif, beberapa faktor afektif yang berkaitanindividu. dengan

pebelajar Faktor-faktor sebagai sosial tersebutlahyang utama, sedangkan faktor-faktorpsikologisbaru akan berperan pada kasus-kasus yang tidak dapat ditemukan oleh jarak sosial.Hal tersebutselarasdengan pendapat Tarigan(1995:252), mendaftarberbagai faktoryang menentukanjaraksosial danjarak psikologis.Faktor sosial mengungkapkan situasi belajaryang baikdantidakbaik,sedangkanfaktor psikologis padadasarnya bersifat afektif.Kemunculan keraguan dan kebingunganterjadi ketikaterdapat perbedaankebudayaanpada saat mengarang.Siswaakan mengalami perasaan salaharah, tekanan, ketakutan,dan sebagainyasebagai akibat adanya pembedaan antara budayadengankenyataan.

(3) akulturasi budaya mendongeng terinternalisasi pada recall memory dongeng karangan siswa. Karangan siswa kelas VII SMP Negeri1 Tumpangdipengaruhi olehakulturasi budayamendongeng. Akulturasidipandangsebagai aspek yangpentingdalam mengarang.Karangan merupakanhasilberbahasa dalam bentuk tulisan. Karangan siswa merupakan ekspresi budaya yang palingnyata dandapatdiamati. Latar belakangbudaya akan terlihat daricarapandangsiswa. Akulturasi ditentukan oleh tingkat jaraksosial (social distance) dan jarakpsikologis(psychological distance)antarasiswa dengan kebudayaan.Jaraksosial merupakan akibatdari beberapafaktoryang memengaruhisiswasebagai anggota kelompok sosialdimasyarakat.Jarak psikologis merupakan akibat dari majemukmenjadi tunggal atau sebaliknya.

(4) recall memorymengomparasikanhipogramdan teks karangansiswa.Dongeng karangan siswa merupakan transformasi teks dari teks dongeng asli (hipogram). Teks mudahdipahamijikadisertakan konteks. Teksterdiriatasrangkaian kalimat yang panjang.Teks merupakan satu permutasian teks- teks lain. Intertekstualitas memandang teks berada di dalamruang satu teks yang ditentukan. Teks diambildariteks-teks lain dan bersifattumpang-tindihdan saling menetralkansatu samalain.Kajian intertekstualberangkatdari asumsi bahwakapan pun karyaditulis,teks tersebut tidak mungkin lahir dari situasi kekosongan budaya.Penulisan suatu karyasastratak mungkindilepaskandari unsur kesejarahan dan pemahaman terhadaptekstersebutpun haruslah mempertimbangkan unsur kesejarahantersebut.

(5)recallmemory yangrendah berdampakpada kemampuan mengorganisasi konsepkarangan. Kemampuansiswadalam menulis kurang.Buktinya, merekamembutuhkan waktu yang lama dalam menuangkan gagasannya. Buku tulisyang ada di hadapannya tetap kosong, tidak adakalimatyang tertulis.Pikirannyamasih mengolah konsep-konsep yang akan dituangkannya. Mereka bingung ketikamenuangkan ide.Siswatidak terbiasa menulis karena menulis bukan sekadar kebiasaan.Kemampuanmenulissiswa juga dipengaruhioleh memoriyang disimpan. 
Dapat disimpulkan bahwa karangan adalah tulisan yangberisi ide atau gagasan melalui kalimat- kalimatyangdirangkai secarautuh, lengkap, dan jelas dan memunyai tujuan tertentu untuk dikomunikasikan kepada pembaca. Jika pembacamampumenangkap maknayangdisampaikan dalam karangan, tujuan dari penulisan karangantersebuttelah tercapai. Karanganmerupakanhasil proses mentalberupabahasatulis.

\section{PENUTUP}

Simpulan

Berdasarkan penganalisisan data danhasil penelitianyangdipaparkan sebelumnya,dapat ditariksimpulan berkenaan dengan proposisi bentuk dan makna asosiatif pada RM dongeng karangan siswa kelas VII SMP Negeri1 Tumpang Kabupaten Malang.Secaramenyeluruh RM dongengkarangansiswa dapat ditunjukkan dalam proposisibentuk danmaknaasosiatif.Simpulan dari penelitian tentang RM, sebagai berikut.

1. Proposisi bentuk pada RM dongeng karangan siswa kelasVII SMP Negeri1 Tumpang Kabupaten Malang berupa proposisi majemuk dan tunggal. Data yang ditemukan dalam penelitian ini menunjukkan dominasi bentuk majemuk - majemuk-delisi dalam dongeng karangan siswa kelas VII. Hal tersebut membuktikan bahwa RM siswa kelasVIImencapaidayaingat paling besar,karenamampu meniru proposisibentuk majemuk ke majemuk. RM dongeng karangan siswakelasVIIteraktualisasi dalam imitasibentuk.Proposisi bentuk majemuk dan tunggaldalamdongeng karangan siswa kelas VII ada yang sama bentuknya dan ada yang beda darihipogram.Perbedaan bentuk tersebutberupapendelisian dan penyubstitusian datatanpamengubah maknayangingin disampaikan.

2. Makna asosiatif pada RM dongeng karangan siswa kelas VII SMP Negeri1 Tumpang Kabupaten Malang berupa makna konotatif, makna stilistik, makna reflektif, maknaafektif,dan maknakolokatif. Data yang ditemukan dalam penelitianini menunjukkandominasi maknareflektif-reflektif padaRM dongeng karangan siswa.RM terejawantah dalam komparasi maknaasosiatif.Penggunaan bahasa dalam karangan siswa sebagai matriks pengetahuan bahasa dapat dilihatdari carapandangsiswa menemukanmaknapotensial bahasa dalam karangan siswa karena dongengkarangansiswa merupakan komparasi dari hipogram danteks transformasi.RM mengomparasikan hipogramdantekskarangan siswa.Komparasi tersebut dibuktikan denganmetode intertekstualitas.Intertekstualitas dalam karangan siswa merupakan satu permutasian tekslain. TeksRMsiswamerupakan transformasi dari hipogram.Karangan siswa dipengaruhi oleh akulturasi budayamendongeng. Karangansiswamerupakan ekspresi budayayang paling nyatadan dapat diamati.Latar belakang budayaakan terlihatdari carapandangsiswa. Akulturasi budayamendongeng berpengaruh padadongeng karangan siswa.RMyang rendah berdampak padapengorganisasian konsep dalam karangan.Jadi, makna yang ada pada karangan siswa samaatau berbeda dari maknahipogram bergantung cara pandang siswatersebut.

\section{Saran}

Berdasarkanhasil penelitiandan diskusihasiltemuan,saran yang diberikan adalahsebagaiberikut. (1) RM tidaklepas dariaktivitasbelajar siswa.RMberperanpenting dalam pembelajaran bahasa.Pembelajaran bahasabertujuan meningkatkan kemampuan berkomunikasi siswa dalambahasa Indonesia dengan baik dan benar, baik secaralisanmaupun tulis. Pembelajaran bahasa tidak dapatdilakukansecara mekanistis, karenaketerampilan berbahasa melibatkanstruktur mental.Pembelajaran hanya dilakukan dengan pelatihan-pelatihan seperti yang dilakukan selama ini.Agar terampil berbicara, siswa dilatih berbicara terus-menerus. Agar terampilmenulis, siswaharus berlatih menulis. Dengan kata lain, siswatidakmenulis secaramekanis seperti yang dilatihkan gurunya. Padawaktu menulis,membaca, menyimak, atau berbicaradi dalam otakterjadiprosesmental sehingga siswa dapat menulis hal-hal baru yang berbeda dengan latihan guru.

Pelatihan diperlukan dalam pembelajaran bahasa tetapi bukan satu-satunya.Melalui pelatihan, siswadiberi kesempatanmelakukan kegiatanberbahasa.Tanpa mencoba berbahasa, tidakmungkinsiswaakan terampil berbahasa. Pelatihan berbahasatidaksekadar untuk melancarkan alatalatujar merepresentasikangagasan.(2) RM dongeng karangan siswa kelasVII ini, juga diharapkan dijadikan motivasibagi peneliti-peneliti selanjutnya, untuk mengadakan penelitian tentang proposisi bentuk dan makna asosiatif sehingga ditemukan karakteristik perbedaannya. (3) Penelitian tentangRM dongeng karangan siswa merupakan penelitian yangmasih langka,sertapenelitianini pun 
memerlukanpengajian yang lebih seksamadanmendalam untukitu diharapkan selanjutnya yanglebihbaik.

\section{DAFTAR RUJUKAN}

BNSP.(2006). Buku panduan penyusunan KTSP. Jakarta: RinekaCipta.

Byrne,D.M.(1971).The attraction paradigm.NewYork: Academic Press.

Chafe, L. Wallace. (1973). Language and memory. Language.Vol.49.No. 2.

Clark,HerbertH.DanEve V.Clark. (1977). Psychologyand language: An introduction to psycholinguistics.New York: Harcourt Brace and Jovanovich, Inc.

Cristeva,Julia.(1980). Desire in language: asemiotic approach to literature and art.Oxford: Basil Blackwell.

Danan dajaja,James. (1977). Foklor Indonesia: Ilmu gosip,dongeng, dan lain-lain. Jakarta: Rineka Cipta.

Drever, James. (1986). Kamus Lengkap Psikologi. (Penerjemah: Nancy Simanjutak).Cetakan 1.Jakarta:PT. Bina Aksara.

Djamarah,S.B. (2003). Psikologi belajar.Jakarta:Rineka Cipta.

Engel,Susan.(2000).Context is everything: The nature of memory. NewYork:W.H.Freeman and Company.

Gie, TheLiang. (1992). Kumpulan karangan. Jakarta: Balai Buku Indonesia.

Kartono, Kartini. (2003). Patologi sosial 3: Gangguan-gangguan kejiwaan. Jakarta:PT. RajaGrafindo Persada.

Mundiri.(2009). Logika.Jakarta: Rajawali Pers.

Riffatere, Michael. (1978). Semioticsof poetry. Bloomington: IndianaUniversity Press.

Shinta, Y. D., Chamalah, E., \& Arsanti, M. (2018). Penerapan Model Pembelajaran Berdasarkan Masalah Dan Media Video Animasi Peristiwa Sosial Bermuatan Pendidikan Multikultural Untuk Meningkatkan Keterampilan Menyusun Teks Eksplanasi.Basindo: Jurnal Kajian Bahasa, Sastra Indonesia, Dan Pembelajarannya, 1(2), 59-71.

Sternberg,Robert J.(2006). Psikologi kognitif. Edisi 4. Yogyakarta:PustakaPelajar.

Tarigan,Henry Guntur.(1995). Argumentasi dan narasi.Jakarta: BalaiPustaka

Teeuw, A.(1988). Sastra dan Ilmu sastra: pengantar ilmu sastra. Yogyakarta:PustakaPelajar.

Walgito,Bimo.(2004). Pengantar psikologiumum.Yogyakarta: Andi.

Yusuf, Haryono. (2001). Teori perkembangan kognitif Jean Piaget. Yogyakarta:Kanisius. 